\title{
Determination of nitrogen dioxide, sulfur dioxide, ozone, and ammonia in ambient air using the passive sampling method associated with ion chromatographic and potentiometric analyses
}

\author{
Alaa A. Salem • Ahmed A. Soliman • Ismail A. El-Haty \\ Received: 3 December 2008 / Accepted: 27 April 2009/Published online: 29 May 2009 \\ (C) The Author(s) 2009. This article is published with open access at Springerlink.com
}

\begin{abstract}
Concentrations of nitrogen dioxide $\left(\mathrm{NO}_{2}\right)$, sulfur dioxide $\left(\mathrm{SO}_{2}\right)$, ozone $\left(\mathrm{O}_{3}\right)$, and ammonia $\left(\mathrm{NH}_{3}\right)$ were determined in the ambient air of Al-Ain city over a year using the passive sampling method associated with ion chromatographic and potentiometric detections. IVL samplers were used for collecting nitrogen and sulfur dioxides whereas Ogawa samplers were used for collecting ozone and ammonia. Five sites representing the industrial, traffic, commercial, residential, and background regions of the city were monitored in the course of this investigation. Year average concentrations of $\leq 59.26,15.15,17.03$, and $11.88 \mu \mathrm{g} / \mathrm{m}^{3}$ were obtained for $\mathrm{NO}_{2}, \mathrm{SO}_{2}, \mathrm{O}_{3}$, and $\mathrm{NH}_{3}$, respectively. These values are lower than the maxima recommended for ambient air quality standards by the local environmental agency and the world health organization. Results obtained were correlated with the three meteorological parameters: humidity, wind speed, and temperature recorded during the same period of time using the paired $t$ test, probability $p$ values, and correlation coefficients. Humidity and wind speed showed insignificant effects on $\mathrm{NO}_{2}, \mathrm{SO}_{2}, \mathrm{O}_{3}$, and $\mathrm{NH}_{3}$ concentrations at $95 \%$ confidence level. Temperature showed insignificant effects on the concentrations of $\mathrm{NO}_{2}$ and $\mathrm{NH}_{3}$ while significant effects on $\mathrm{SO}_{2}$ and $\mathrm{O}_{3}$ were observed. Nonlinear correlations $\left(R^{2} \leq\right.$ 0.722 ) were obtained for the changes in measured concentrations with changes in the three meteorological parameters. Passive samplers were shown to be not only precise $(\mathrm{RSD} \leq 13.57)$ but also of low cost, low technical demand, and expediency in monitoring different locations.
\end{abstract}

A. A. Salem $(\square) \cdot$ A. A. Soliman $\cdot$ I. A. El-Haty

Department of Chemistry, College of Science,

United Arab Emirates University,

Al-Ain P.O. Box 17551, UAE

e-mail: Asalem@uaeu.ac.ae
Keyword Nitrogen dioxide - Sulfur dioxide - Ozone ·

Ammonia $\cdot$ Determination $\cdot$ Ambient air $\cdot$ Ion

chromatography Potentiometry Ion selective electrode

\section{Introduction}

The weather in Al-Ain city is tropical, deficient in rainfall, and characterized by two distinctive seasons; a dry hot spring-summer (April-November) with average temperature of $35^{\circ} \mathrm{C}$, and a warm autumn-winter (December-March) with slight rainfalls and average temperature of $20^{\circ} \mathrm{C}$. The city contains impressive number of parks and palms. Traffic congestion, cement, fertilizers and paint factories, and degradation processes of plants and sand dunes surrounding the city are the main sources for nitrogen dioxide, sulfur dioxide, ozone, and particulate matters (Yagoub 2004). The 2004 UAE Ministry of Health annual statistical report stated that out of 149,484 patients treated at Al-Ain public health clinics, 134,699 (90.1\%) were suffering from allergic rhinitis, diseases of the upper respiratory tract, chronic bronchitis, asthma, and other diseases of respiratory system. This number represented around $46 \%$ of patients treated at public health clinics in the whole country (380,932 patients). As there were no reported data about the quality of the ambient air in the city, we have been motivated to measure $\mathrm{NO}_{2}, \mathrm{SO}_{2}, \mathrm{O}_{3}$, and $\mathrm{NH}_{3}$ in air as possible causes for such high incidence of respiratory diseases in the city. Concentration values of 14.82-27.86, 16.58-43.43, and 18.25$35.80 \mu \mathrm{g} / \mathrm{m}^{3}$ were reported for $\mathrm{NO}_{2}, \mathrm{SO}_{2}$, and $\mathrm{O}_{3}$, respectively, in some adjacent cities of Kuwait and Oman (Bouhamra and Abdul-Wahab 1999).

Passive samplers are small, silent, and reliable; do not need electricity; and are less expensive. They can be used for indoors and outdoors monitoring in rural, urban, arctic, 
and tropical environments where they can provide exposure profiles with high quality (Gorecki and Namiesnik 2002). Samplers do not need field calibration, air volume measurements, and technical demands at the sampling site. They are suitable for determining spatial distribution of gases and establishing atmospheric monitoring networks (Carmichael et al. 2003; Cox 2003; Cruz et al. 2004).

Passive samplers simplify the analytical procedure at the sampling step and minimize sample decomposition during transport and storage. Although its low sampling rates necessitate long sampling times at low concentrations, the time-weighted average concentrations of the analytes produced by the samplers are more useful in assessing long-term impacts of pollutants. Analytical results obtained by passive sampling can be affected by temperature, humidity, and air velocity. Detection limit is dependent on the sampling rate, time, and sensitivity of the detection systems used (Namiesnik et al. 2005).

Since the first sampler described by Palmes for collecting sulfur dioxide (Palmes and Gunnison 1973), several samplers developed by the Swedish Environmental Research Institute, Rupprecht and Patashnick Company (USA), Laboratory of Aerology in Toulouse (France), CSISRO (Australia), Radiello, and others. They generally rely on diffusion of contaminant molecules across concentration gradients defined by Fick's first law of diffusion. Diffused contaminants are trapped on filters impregnated with reagents consisted of $\mathrm{NaOH}$, triethanolamine, $\mathrm{Na}_{2} \mathrm{CO}_{3}$, tetrachloromercurate, TEA, $\mathrm{NaI}+\mathrm{Na}_{2} \mathrm{CO}_{3}$, citric acid, or phosphoric acid for trapping $\mathrm{SO}_{2}, \mathrm{NO}_{2}$, or $\mathrm{NH}_{3}$ (Lan et al. 2004).

The IVL passive sampler was designed to avoid the effects of wind, temperature, humidity, interferences, and losses during storage. It was verified against established continuous measurement techniques. Accredited IVL samplers were used in the global atmospheric watch program (GAW) conducted by the World Meteorological Organization to measure $\mathrm{SO}_{2}$, $\mathrm{NH}_{3}$, and $\mathrm{O}_{3}$ into 50 stations in Asia, Africa, South America, and Europe (Carmichael et al. 2003).

Ogawa passive samplers have been extensively used in monitoring $\mathrm{SO}_{2}, \mathrm{NO}_{\mathrm{x}}, \mathrm{O}_{3}$, and other gases by the American Environmental Protection Agency and Harvard School of Public Health. They were used in monitoring urban $\mathrm{O}_{3}$ in national parks (Ray 2001), $\mathrm{NO}_{2}$ emissions from highway traffic (Gilbert et al. 2003), and $\mathrm{NO}_{2}$ in some MexicanUSA border cities. Good agreements between results from Ogawa's samplers and continuous gas analyzers were obtained (Mukerjee et al. 2004). Samplers developed by Warashina were applied to monitor $\mathrm{SO}_{2}, \mathrm{NO}_{2}, \mathrm{NO}, \mathrm{NH}_{3}$, $\mathrm{HCl}, \mathrm{HNO}_{3}, \mathrm{HCOOH}$, and $\mathrm{CH}_{3} \mathrm{COOH}$ concentrations in air (Lan et al. 2004).

Harvard samplers were used to measure outdoor, indoor, and school children's personal exposure of ozone. Weekly average outdoor concentrations of $0.011-0.030,0.015-$
0.042, and 0.0013-0.0064 ppm were reported for urban, suburban areas, and personal exposures, respectively. Airconditioned homes displayed very low indoor $\mathrm{O}_{3}$ concentrations relative to homes using open windows and fans for ventilation (Lee et al. 2004).

Several types of samplers have been used for monitoring ambient ozone in Europe (Blum et al. 1997; Bytnerowicz et al. 2002), North America (Brace and Peterson 1998; Cox and Malcolm 1999; Ray 2001; Bytnerowicz et al. 2001; Frączek et al. 2003), and at a global scale (Carmichael et al. 2003). Ogawa samplers have been the most commonly used in USA (Koutrakis et al. 1993). Correlation between ozone concentrations measured by Ogawa samplers and UV continuous monitoring gave linear correlations up to a dose of $52,500 \mathrm{ppb} \mathrm{O}_{3} \times \mathrm{h}$ with $R^{2}=0.9949$. The reliability of the samplers for long time monitoring of $\mathrm{O}_{3}(477 \mathrm{~h}$ at $110 \mathrm{ppb})$ was confirmed. The samplers have also shown very high precision with relative standard deviation of $4.8 \%$ (Bytnerowicz et al. 2004).

Several types of $\mathrm{SO}_{2}$ passive samplers have been described. A comparison between $\mathrm{SO}_{2}$ passive and active samplers at both urban and remote sites in Sweden demonstrated close agreement between the two methods within $\pm 15 \%$ (Ferm and Svanberg 1998). Passive samplers' performances in determining $\mathrm{SO}_{2}$ concentrations in tropical environment were compared with active methods (Cruz et al. 2004).

A poorly sensitive spectrophotometric method for determining $\mathrm{NO}_{2}$ in air based on converting $\mathrm{NO}_{2}$ into nitrite ions which was subsequently coupled with azodyes was reported (Pandurangappa and Balasubranian 1996). Chemiluminescence sensitive methods based on catalytic reduction of $\mathrm{NO}_{2}$ to $\mathrm{NO}$ which was subsequently reacted with ozone or luminal were also reported (Robinson et al. 1999; Mikuska and Vecera 2000). Laser-induced fluorescence detection was used in determining $\mathrm{NO}_{2}$, but its high cost prevented it from popular use (Thornton et al. 2000; Matsumoto et al. 2001). $\mathrm{NO}_{2}$ was also determined using optical sensors (Do and Shieh 1996), electrochemical sensors (Shimizu et al. 2000), and passive sampling methods (Yanagisawa and Nishimura 1982).

Sulfur dioxide in atmosphere is associated with adverse health effects, including respiratory and cardiovascular diseases. $\mathrm{SO}_{2}$ exposure daily levels not exceeding $125.00 \mu \mathrm{g} / \mathrm{m}^{3}$ and mean annual levels below $50.00 \mu \mathrm{g} / \mathrm{m}^{3}$ are the maxima recommended by the World Health Organization guidelines (World Health 2000). Spectrophotometric (Segundo and Rangel 2001), chemiluminescence (Wu et al. 1998), ion chromatographic (Yang et al. 2007), spectrofluorometric (Yang et al. 2002), potentiometric (Ibrahim et al. 1996), and amperometric (Carballo et al. 2003) methods were reported for determining $\mathrm{SO}_{2}$ in atmosphere. Online determinations of $\mathrm{SO}_{2}$ in air based on sample collection using chromatomembrane cells or gas permeation denuders fol- 
lowed by spectrophotometric flow injection analyses were also reported (Sritharathikhun et al. 2004; Guo et al. 2003). A method based on passive samplers was also used in monitoring of $\mathrm{SO}_{2}$ (Yang et al. 2007).

Spectrophotometric, chemiluminescene, potentiometric, amperometric, and passive sampling methods were reported for determining ozone in ambient air (Eipel et al. 2003; Huang and Dasgupta 1997; Shiavon et al. 1990).

Colorimetric methods based on Nessler and Indophenol blue reagents are the most common methods for determining $\mathrm{NH}_{3}$ (Stern 1968). The use of mercury or cyanide ions included in the two reagents make these methods hazardous. Methods based on potentiometry (Egan and Dubois 1974), ion chromatography (Kifune and Oikawa 1979), chemiluminescence (Demmers et al. 1998), denuders (Leuning et al. 1967), gas scrubbers (Fehsenfeld 1995), spectrophotometry (Przybylko et al. 1995), and remote detection using near infrared transmission (Christie et al. 2003) were reported. Direct readings of ammonia in atmosphere using bilayer lipid membrane sensor (Thompson et al. 1983), gas-sensitive semiconductor capacitor (Winquist et al. 1984), fiber-optic fluorescing sensor (Sellien et al. 1992), gas-sensitive electrode (Hjuler and Dam-Johansen 1993), and amperometric sensors (Strehlitz et al. 2000) were also reported.

As there are no reported data about the air quality of $\mathrm{Al}$ Ain city before the date of this study, this work aimed to determine the average concentrations of $\mathrm{NO}_{2}, \mathrm{SO}_{2}, \mathrm{O}_{3}$, and $\mathrm{NH}_{3}$ in the city ambient air. The second aim of this study was to find a probable cause for the relatively high incidences of acute respiratory attacks reported by the ministry of health annual statistical report in 2004. This report stated that around $46 \%$ of the patients treated at the public health clinics in the country suffered from acute respiratory diseases and were from the city inhabitants. Passive sampling extraction technique associated with ion chromatographic and potentiometric analyses have been used for this investigation.

\section{Experimental}

Materials and reagents

Analytical grade chemicals were used throughout. Sodium hydroxide, potassium hydroxide, sodium iodide, sodium nitrite, potassium carbonate, triethanolamine, hydrogen peroxide, citric acid, ammonium chloride, and EDTA were purchased from Sigma-Aldrich (St. Louis, MO, USA) or Merck (Darmstad, Germany). Deionized water was used throughout.

\section{Standard solutions}

Standard solutions ranging from $1.0-20.0 \mathrm{ppm}$ in nitrite, nitrate, and sulfate were prepared using $100 \mathrm{ppm}$ stock standard solution consisted of a mixture of nitrite, nitrate, and sulfate purchased from Dionex (Titan Way Sunnyvale, CA, USA).

A standard solution prepared by mixing $7.90 \mathrm{~g} \mathrm{NaI}$ with $0.88 \mathrm{~g} \mathrm{NaOH}$ into $100.0 \mathrm{ml}$ methanol and stirred in ultrasonic bath was used as impregnation solution for the $\mathrm{NO}_{2}$ samplers' filters.

A standard solution prepared by dissolving $5.60 \mathrm{~g} \mathrm{KOH}$ into $50.00 \mathrm{ml}$ methanol and mixed with $10.00 \mathrm{ml}$ glycerol. The solution was made up to the $100 \mathrm{ml}$ by methanol and used as impregnation solution for $\mathrm{SO}_{2}$ samplers' filters.

A standard solution prepared by dissolving $0.3 \mathrm{~g}$ $\mathrm{NaNO}_{2}, 0.28 \mathrm{~g} \mathrm{~K}_{2} \mathrm{CO}_{3}$, and $1.00 \mathrm{ml}$ glycerol into $100.00 \mathrm{ml}$ of deionized water was used as impregnating solution for ozone samplers' filters.

A standard solution prepared by dissolving $2.00 \mathrm{~g}$ citric acid and $1.0 \mathrm{ml}$ glycerol into $50.00 \mathrm{ml}$ deionized water. The solution was made up to $100.00 \mathrm{ml}$ by ethanol and used as impregnating solution for ammonia samplers' filters.

A $10^{-3}-\mathrm{M}$ triethanolamine and $0.3 \%$ hydrogen peroxide were used as extracting solutions for nitrite and sulfate ions, respectively, whereas deionized water was used for extracting nitrate and ammonium ions.

\section{Apparatus}

IVL passive samplers (Swedish Environmental Research Institute, Stockholm, Sweden) were used for collecting $\mathrm{NO}_{2}$ and $\mathrm{SO}_{2}$ from air. The sampler consisted of a bottom-led, impregnation filter, passive sampler tube, Teflon filter; steel net, and front led (Fig. 1a). The steel net and the Teflon membrane filter (Millipore filters, $1.0 \mu \mathrm{m}$ pore size and $25 \mathrm{~mm}$ pore diameter) are used to prevent particles collection, turbulence inside the sampler, and to facilitate laminar diffusion inside the sampler tube. A Whatman-40 filter paper (Springfield Mill, Maidstone Kent, UK) was used as impregnating filters.

Ogawa passive sampler (Ogawa, Pompano Beach, FL, USA) was used for collecting $\mathrm{O}_{3}$ and $\mathrm{NH}_{3}$. The sampler consisted of a solid Teflon cylinder with two open, unconnected sides. Each side contains an impregnating cellulose filter mounted between two stainless steel screens $\left(0.152 \mathrm{~cm}^{2}\right.$ open area, $0.02 \mathrm{~cm}$ thick $)$ and situated behind a diffusion-barrier end cap containing 25 holes $\left(0.785 \mathrm{~cm}^{2}\right.$ open area, $0.6 \mathrm{~cm}$ thick). The sampler body (6) has outer diameter of $2 \mathrm{~cm}$ and length of $3 \mathrm{~cm}$. Two independent cavities, $1.4 \mathrm{~cm}$ inner diameter contain diffusive barrier end-caps (1), reactive filters (3) between the inner and outer stainless steel screens (2) and retainer rings (4) over base pads (5; Fig. 1b).

An ICS-90 ion chromatograph (Dionex, Titan Way Sunnyvale, CA, USA) supported with an AS9-SC anion analytical column and anion micro-membrane suppressor 


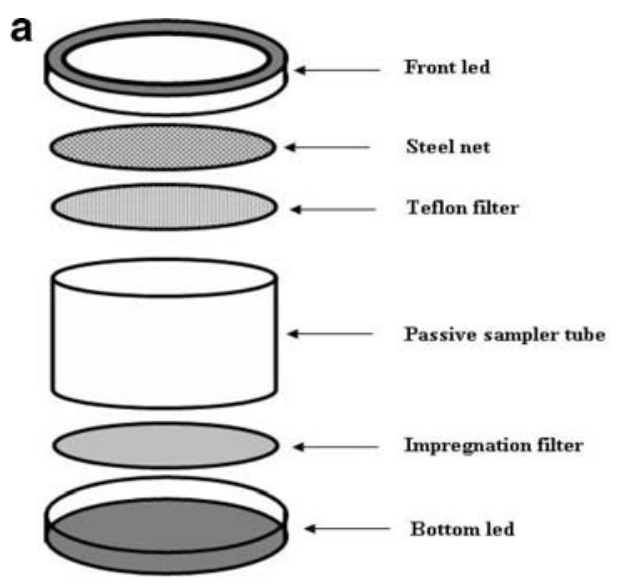

b

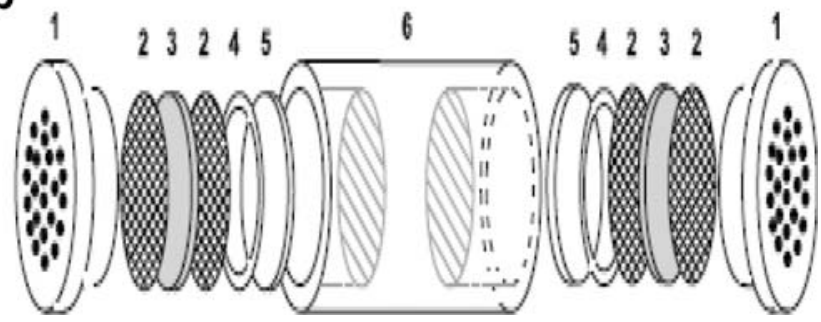

Fig. 1 Components of a: The IVL passive sampler used for collecting nitrogen dioxides and sulfur dioxide. b: The Ogawa passive sampler used for collecting ozone and ammonia: (1) Diffusive barrier endcaps, (2) inner and outer stainless steel screens, (3) reactive filters, (4) retainer rings, (5) over base pads, (6) sampler body

was used for measuring nitrite, sulfate, and nitrate ion concentrations. An ammonia ion selective electrode model IS 570-NH $\mathrm{NH}_{3}$ (PHILIPS, Hamburg, Germany) was used for potentiometric measurements of ammonium ion.

Procedures

\section{Sites selection}

Sites represent the industrial, traffic, commercial, residential, and background regions of the city were selected for this study.

\section{Impregnation}

Samplers were cleaned with methanol and deionized water. IVL filters were placed on the sampler's bottom lids, and Ogawa filters were placed on Erlenmeyer flasks. Filters were impregnated using 50.0- $\mu$ l portions of any of the impregnation solutions given in "Standard solutions" and left to dry at $100^{\circ} \mathrm{C}$ for $30 \mathrm{~min}$. The samplers were then mounted and placed in the transport boxes until deploying.

\section{Deploying}

Samplers were mounted on shielding plates $\left(10 \times 15 \mathrm{~cm}^{2}\right.$, $5-\mathrm{cm}$ rims) with their open sides oriented downwards to protect them from direct exposure to sunlight, wind, dust, and rain falls. A double-sided adhesive tape and clips were used to mount the IVL and Ogawa samplers, respectively. Exposure times of 14 days were applied for all samplers, after which samplers were transferred to the lab for analyses. Blank samplers were treated similarly and kept in the laboratory during the sampling period.

\section{Extraction}

Samplers exposed to ambient air were collected; its filters were taken out using clean forceps and then immersed into $10.0-\mathrm{ml}$ extraction solutions placed in clean plastic vials ("Standard solutions"). The vials were then closed and shacked carefully to extract the ions from the filters. The vials were then stored in a refrigerator at $4^{\circ} \mathrm{C}$ until analyses.

\section{Analyses}

Ion chromatography: Nitrite, sulfate, and nitrate ions were determined using IC. Dilute sulfuric acid was used as a regenerant and $1.8 \mathrm{mM}$ sodium carbonate was used as mobile phase. Flow rate of $1.0 \mathrm{ml} / \mathrm{min}$ with $20 \mu \mathrm{l}$ injection volume and conductivity detector were used. Calibration graphs of integrated areas versus concentrations were constructed using standard solutions described in "Standard solutions." Samplers' extracts were measured under the same conditions.

Ion selective electrode: Calibration of ammonia ion selective electrode was done using standard ammonium chloride solutions in the concentrations range $10^{-4}-10^{-1} \mathrm{M}$. A $10.0-\mathrm{ml}$ standard $\mathrm{NH}_{4} \mathrm{Cl}$ solution was mixed with $1.0 \mathrm{ml}$ of standard alkaline EDTA solution (0.1 M EDTA in $1.0 \mathrm{M} \mathrm{NaOH})$. The solution was stirred for $1.0 \mathrm{~min}$ to release the ammonia gas and the potential was measured using the ammonia ISE electrode versus a calomel reference electrode. Calibration curve of potential in $\mathrm{mV}$ versus $\log$ concentration was plotted. Linear graphs with average slopes ranging from 52 to $55 \mathrm{mV}$ were obtained; $5.0 \mathrm{ml}$ portions of the extracts were put in the cell, mixed with $0.5 \mathrm{ml}$ portions of alkaline EDTA solution, and stirred for $1.0 \mathrm{~min}$. Potential were then recorded, and concentrations were determined from the calibration curve.

\section{Calculations}

Calculation of $\mathrm{NO}_{2}$ concentration in air: Concentration of $\mathrm{NO}_{2}$ was calculated using Eq. 1, given by the IVL protocol (Royset and Sivertsen 1998).

$$
C_{\left(\mathrm{NO}_{2}\right)}=\frac{m\left(\mathrm{NO}_{2}^{-}\right) \times v}{t \times 0.0323}
$$


where $C_{\left(\mathrm{NO}_{2}\right)}$ is the concentration of the sampled gas in units of microgram per cubic meter, $m\left(\mathrm{NO}_{2}^{-}\right)$is the concentration of $\mathrm{NO}_{2}^{-}$determined in the extract in the units of microgram per milliliter, $v$ is the extraction volume of the filter and equals $5.0 \mathrm{ml}$ for the IVL samplers used, $t$ is the time of exposure in days (i.e., $24 \mathrm{~h}$ units) and 0.0323 is the sampler uptake rate for $\mathrm{NO}_{2}$ in units of cubic meter per day.

Calculation of $\mathrm{SO}_{2}$ concentration in air: The air concentration of $\mathrm{SO}_{2}$ was calculated using Eq. 2, given by the IVL protocol (Royset and Sivertsen 1998).

$C_{\left(\mathrm{SO}_{2}\right)}=\frac{m\left(\mathrm{SO}_{4}^{2-}\right) \times v \times 0667}{t \times 0.0277}$

where $C_{\left(\mathrm{SO}_{2}\right)}$ is the concentration of the sampled gas in the units of microgram per cubic meter, $m\left(\mathrm{SO}_{4}^{2-}\right)$ is the concentration of $\mathrm{SO}_{4}^{2-}$ determined in the extract in the units of microgram per milliliter, $v$ is the extraction volume of the filter in $\mathrm{ml}$ and equals $5.0 \mathrm{ml}, 0.667$ is the conversion factor from $\mathrm{SO}_{4}^{2-}$ to $\mathrm{SO}_{2}, t$ is the time of exposure in days ( $24 \mathrm{~h}$ units) and 0.0277 is the uptake rate for $\mathrm{SO}_{2}$ in units of cubic meter per day.

Calculation of $\mathrm{O}_{3}$ concentration in air: The air concentration of $\mathrm{O}_{3}$ was calculated using Eq. 3, given by Ogawa protocol (Harvard School of Public Health, Department of Environmental Health 2001).

$C_{\left(\mathrm{O}_{3}\right)}=\frac{m\left(\mathrm{NO}_{3}^{-}\right) \times v \times 18.09}{t}$

where $C_{\left(\mathrm{O}_{3}\right)}$ is the concentration of the sampled gas in the units of microgram per milliliter, $m\left(\mathrm{NO}_{3}^{-}\right)$is the concentration of $\mathrm{NO}_{3}^{-}$determined in the extract in units of microgram per milliliter, $v$ is the extraction volume of the filter in $\mathrm{ml}, t$ is the time of exposure in minutes, 18.09 is the constant includes conversion factor from $\mathrm{NO}_{3}^{-}$to $\mathrm{O}_{3}$ and the uptake rate for $\mathrm{O}_{3}(21.8 \mathrm{ml} / \mathrm{min})$.

Calculation of $\mathrm{NH}_{3}$ concentration in air: The air concentration of $\mathrm{NH}_{3}$ was calculated using Eq. 4, given by Ogawa protocol (Yokohama City Research Institute for Environmental Science 2005, 2006).

$C_{\left(\mathrm{NH}_{3}\right)}=\frac{m\left(\mathrm{NH}_{3}\right) \times v \times \alpha}{t}$

where $C_{\left(\mathrm{NH}_{3}\right)}$ is the concentration of the sampled gas in units of microgram per cubic meter, $m\left(\mathrm{NH}_{3}\right)$ is the concentration of $\mathrm{NH}_{3}$ determined in the extract in the unit of $\mathrm{ng} / \mathrm{ml}, v$ is the extraction volume of the filter in $\mathrm{ml}$ and equals $8.0 \mathrm{ml}, t$ is the time of exposure in minutes, and $\alpha=43.8 \mathrm{ppb} . \mathrm{min} / \mathrm{ng}$.

\section{Results and discussion}

Ion chromatograms of the standard Dionex solutions consisted of nitrite, sulfate and nitrate ions at different concentrations were measured using $20.0 \mu \mathrm{l}$ injection volumes, sodium carbonate $\left(1.8 \times 10^{-3} \mathrm{M}\right)$ as mobile phase and a flow rate of $1.0 \mathrm{ml} / \mathrm{min}$. The peaks at $7.99 \pm 0.10$ $(n=4), 12.99 \pm 0.14(n=4)$, and $18.59 \pm 0.28(n=4)$ minutes were assigned to nitrite, nitrate, and sulfate ions, respectively. Calibration graphs were obtained by plotting the integrated areas versus concentrations. Linear dynamic ranges from 0.5 to $100 \mathrm{ppm}$ were obtained for the three investigated ions with detection limits of $0.1,0.05$ and 0.05 ppm, respectively.

Passive samplers deployed in different city sites were collected after 14 days exposure time intervals. A total of 26 batches of measurements over 52 weeks were carried out. $\mathrm{NO}_{2}{ }^{-}, \mathrm{SO}_{4}{ }^{2-}$, and $\mathrm{NO}_{3}{ }^{-} \mathrm{NH}_{4}{ }^{+}$ions were extracted from the samplers and analyzed using ion chromatography or ion selective electrodes. Concentrations of the corresponding gas pollutants were calculated using Eqs. 1-4 ("Calculations") The results obtained were correlated with the humidity, wind speed, and temperature meteorological parameters recorded by the local Weather Forecast Department during the same period of time.

Nitrogen dioxide

Nitrogen dioxide diffused through the sampler filter reacts with iodide ions and converted into nitrite ion according to equation (5)

$I^{-}+\mathrm{NO}_{2} \stackrel{\mathrm{NaOH}}{\longrightarrow} \mathrm{NO}_{2}^{-}+I_{2}$

Nitrite ions were extracted into $10^{-3} \mathrm{M}$ triethanolamine and its concentrations were measured using IC. Atmospheric $\mathrm{NO}_{2}$ concentrations were calculated using Eq. 5. Variations in $\mathrm{NO}_{2}$ concentrations during the period Feb 2005 to Feb. 2006 for the industrial, traffic, commercial, residential, and background regions are shown in Fig. 2. $\mathrm{NO}_{2}$ concentrations in $\left(\mu \mathrm{g} / \mathrm{m}^{3}\right)$ and its descriptive statistical analysis are given in Table 1. Average concentrations from $35.50 \mu \mathrm{g} / \mathrm{m}^{3}$ in residential to $59.26 \mu \mathrm{g} / \mathrm{m}^{3}$ in traffic regions were obtained. Median concentrations between $34.12 \mu \mathrm{g} / \mathrm{m}^{3}$ (in commercial) and $60.15 \mu \mathrm{g} / \mathrm{m}^{3}$ (in the traffic) regions were obtained. High $\mathrm{NO}_{2}$ concentrations at the traffic site can be attributed to traffic congestion caused by the large numbers of vehicles releasing $\mathrm{NO}_{2}$. The background concentrations varied from 1.0 to $7.03 \mu \mathrm{g} / \mathrm{m}^{3}$. Concentration values in the ranges of $9.18-55.44,43.25-80.90,26.03-51.38$, and $26.46-52.32 \mu \mathrm{g} / \mathrm{m}^{3}$ were obtained in industrial, traffic, commercial, and residential regions, respectively. These values generally lie below the air quality standards recommended by the local environmental agency- $150 \mu \mathrm{g} / \mathrm{m}^{3}$ 


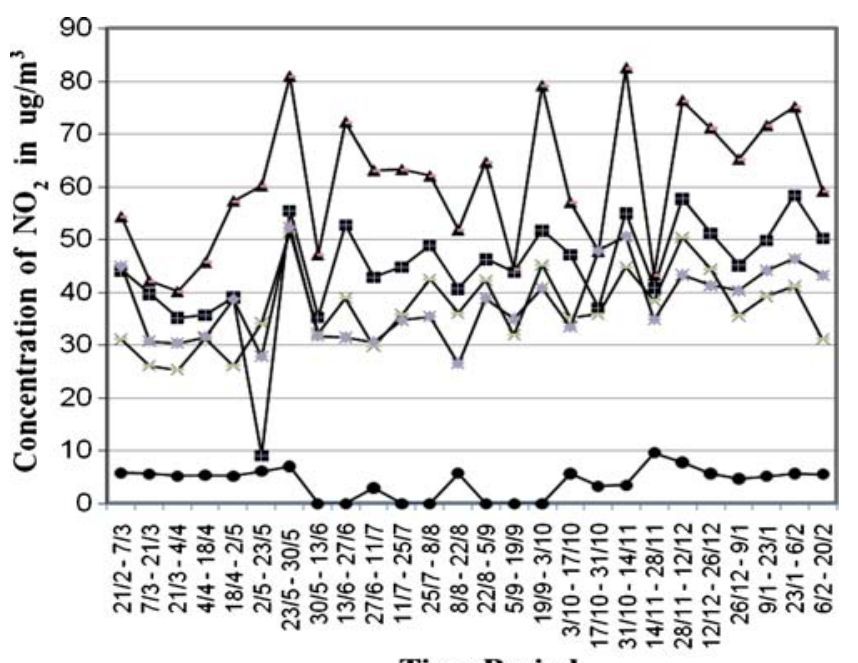

Time Period

Fig. 2 Concentrations of $\mathrm{NO}_{2}$ in $\left(\mu \mathrm{g} / \mathrm{m}^{3}\right)$ at different sites versus time in the period from 21st Feb. 2005 to 20th Feb. 2006. Measurements were done in 26 batches each of which lasted 14 days exposure interval. (filled diamonds) background area, (filled squares) industrial area, (filled triangles) traffic area, (ex marks) commercial area and (asterisks) residential area

as 24-h average - and the WHO (Environmental Agency Abu 2004).

Sulfur dioxide

Sulfur dioxide diffused through the sampler filter reacts with $\mathrm{KOH}$ resulting in the formation of sulfite ions according to equation (6)

$\mathrm{SO}_{2}+\mathrm{KOH} \stackrel{\text { Glycerol }}{\longrightarrow} \mathrm{SO}_{3}^{--}+2 \mathrm{~K}^{+}$

Sulfite ions produced were extracted into $0.3 \%$ hydrogen peroxide to be converted into sulfate ions whose concentrations were measured using IC. Atmospheric $\mathrm{SO}_{2}$ concentrations were calculated using Eq. 6. Variations in $\mathrm{SO}_{2}$ concentrations are shown in Fig. 3 for the industrial, traffic, commercial, residential, and background regions. $\mathrm{SO}_{2}$ concentrations $\left(\mu \mathrm{g} / \mathrm{m}^{3}\right)$ and its descriptive statistical analysis are given in Table 1. Average concentrations varying between $11.82 \mu \mathrm{g} / \mathrm{m}^{3}$ (in residential) and $15.15 \mu \mathrm{g} / \mathrm{m}^{3}$ (in traffic) regions were recorded. The median concentrations varied from $10.36 \mu \mathrm{g} / \mathrm{m}^{3}$ in residential to $142.47 \mu \mathrm{g} / \mathrm{m}^{3}$ in traffic regions. $\mathrm{SO}_{2}$ concentrations in different sites were generally found close to each other $\left(11.82-15.15 \mu \mathrm{g} / \mathrm{m}^{3}\right)$. This might be attributed to the fact that sulfur dioxide originates from nonpoint sources scattered in the city such as aerosols, fertilizer, and emissions form plant degradation. The maximum $\mathrm{SO}_{2}$ emission in the city was found during the summer time (July-August) where the temperature reaches $45-50^{\circ} \mathrm{C}$ (Fig. 3). The average $\mathrm{SO}_{2}$ concentrations in all sites were found two to three times higher than the average background concentrations $\left(5.92 \mu \mathrm{g} / \mathrm{m}^{3}\right)$. These values are generally below the air quality standards recommended by the local environmental agency $150 \mu \mathrm{g} / \mathrm{m}^{3}$ as 24-h average (Environmental Agency Abu 2004) and the WHO.

\section{Ozone}

Diffused ozone through the passive sampler's filter oxidizes $\mathrm{NO}_{2}{ }^{-}$on the filter to $\mathrm{NO}_{3}{ }^{-}$according to equation (7).

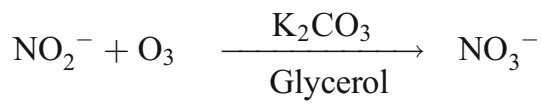

Nitrate ions produced were extracted into deionized water and determined using IC. Variations in $\mathrm{O}_{3}$ concentrations in the period April 2005 to April 2006 are shown in Fig. 4 for the industrial, traffic, commercial, residential, and background regions. Table 2 shows the obtained $\mathrm{O}_{3}$ concentrations $\left(\mu \mathrm{g} / \mathrm{m}^{3}\right)$ and its descriptive statistical analysis. Average $\mathrm{O}_{3}$ concentrations varying from $8.56 \mu \mathrm{g} / \mathrm{m}^{3}$ (in the traffic) to $17.03 \mu \mathrm{g} / \mathrm{m}^{3}$ (in the background) regions were obtained. The median concentrations varied from $7.82 \mu \mathrm{g} / \mathrm{m}^{3}$ (in the traffic) to $15.52 \mu \mathrm{g} / \mathrm{m}^{3}$ (in the background) regions. The highest ozone concentration was found in the background site $\left(17.03 \mu \mathrm{g} / \mathrm{m}^{3}\right)$. The reason can be attributed to what is called "urban quenching." Ozone concentrations are generally lower in urban areas than in rural areas because urban areas are having higher levels of nitrogen oxides. The latter react with ozone and resulting in decreasing its concentration (De Leeuw et al. 1999). Negative correlations between ozone and $\mathrm{NO}_{2}$ concentrations can be deduced from data shown in Tables 1 and 2 as well as from Figs. 2 and 4.

Ozone in the industrial, traffic, commercial, and residential regions showed concentrations in the ranges of 6.85-21.26, 4.67-18.77, 7.75-17.61, and 8.66-20.71 $\mu \mathrm{g} / \mathrm{m}^{3}$, respectively. These values are generally below the air quality standards recommended by the local environmental agency; $120 \mu \mathrm{g} / \mathrm{m}^{3}$ as 8 -h average and the WHO (Environmental Agency Abu 2004).

\section{Ammonia}

Ammonia gas diffused through the sampler's filter impregnated with citric acid is converted into ammonium ions as given in equation (8).

$\mathrm{NH}_{3}+\mathrm{C}_{6} \mathrm{H}_{8} \mathrm{O}_{7} \stackrel{\text { Glycerol }}{\longrightarrow} \mathrm{HN}_{4}^{+}+\mathrm{C}_{6} \mathrm{H}_{7} \mathrm{O}_{7}^{-}$

Ammonium ions produced were extracted into deionized water and potentiometrically determined using the ammonia gas ion selective electrode.

Variations in ammonia concentrations over the period April 2005 to April 2006 for the industrial, traffic, commercial, residential, and background regions are shown in Fig. 5. Concentrations in $\mu \mathrm{g} / \mathrm{m}^{3}$ and its descriptive 


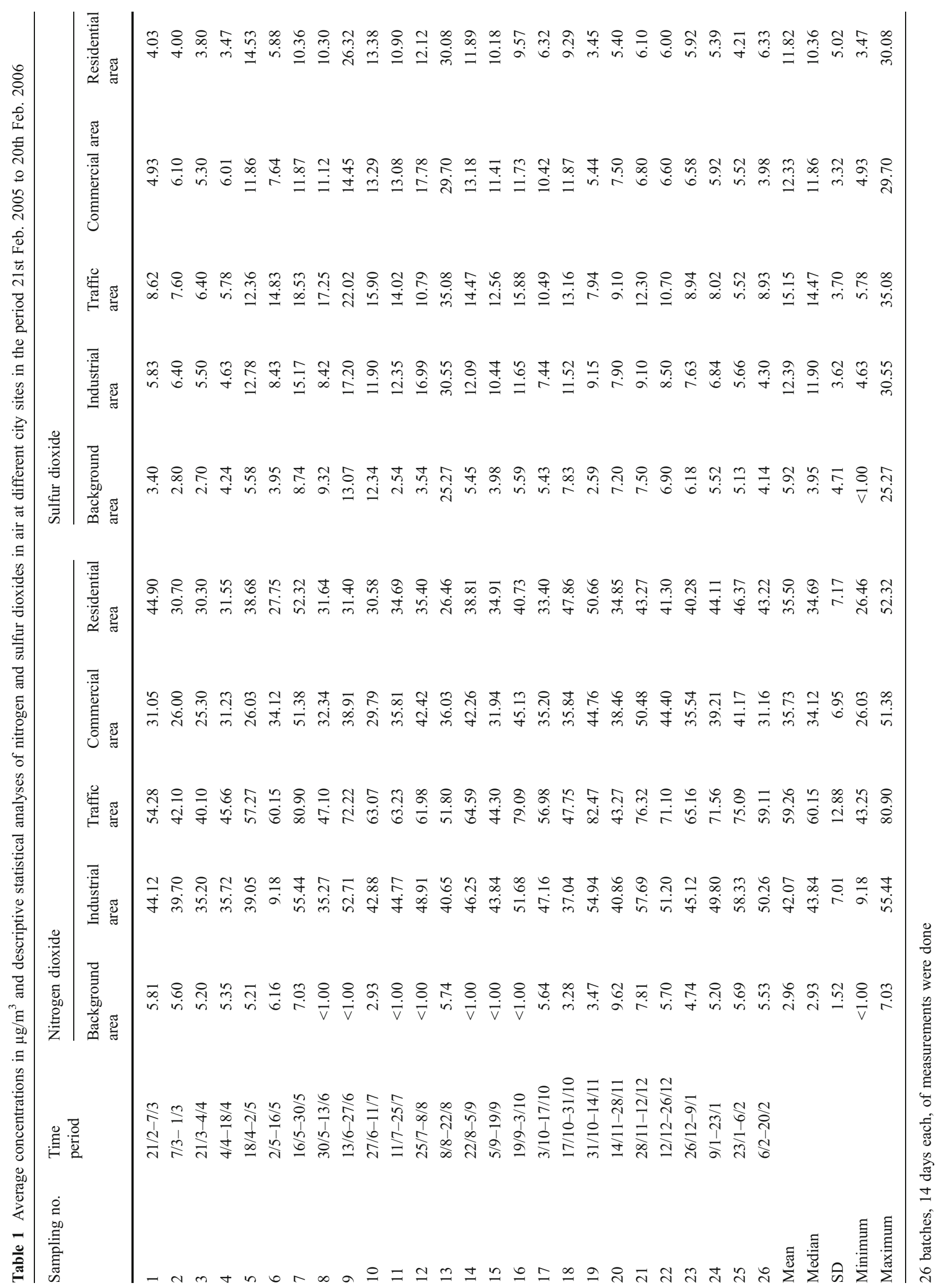




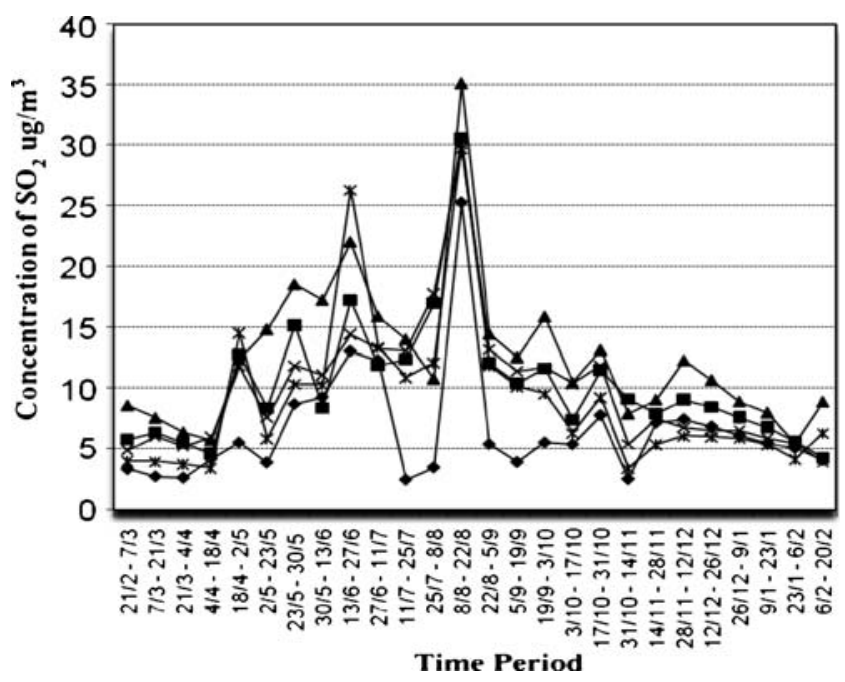

Fig. 3 Concentration of $\mathrm{SO}_{2}$ in $\left(\mu \mathrm{g} / \mathrm{m}^{3}\right)$ at different sites versus time in the period from 21st Feb. 2005 to 20th Feb. 2006. Measurements were done in 26 batches each of which lasted 14 days exposure interval. (filled diamonds) background area, (filled squares) industrial area, (filled triangles) traffic area, (ex marks) commercial area and (asterisks) residential area

statistical analysis are shown in Table 2. Average $\mathrm{NH}_{3}$ concentrations varied from $7.81 \mu \mathrm{g} / \mathrm{m}^{3}$ (in the industrial) to $11.88 \mu \mathrm{g} / \mathrm{m}^{3}$ (in the traffic) regions were obtained. The median concentrations varied from 3.23 to $10.26 \mu \mathrm{g} / \mathrm{m}^{3}$ in the same regions. The highest year average for ammonia's concentration was found in the traffic site $\left(11.88 \mu \mathrm{g} / \mathrm{m}^{3}\right)$. Variations in $\mathrm{NH}_{3}$ concentrations in all sites were found generally similar, $0.69-38.67,1.80-43.93,0.71-41.24$, and $0.16-53.74 \mu \mathrm{g} / \mathrm{m}^{3}$ in industrial, traffic, commercial, and residential regions, respectively. The reason can be attributed to the fact that ammonia gas is produced from ammoniacontaining fertilizers and wastewaters produced from the municipality treatment plant and used in irrigating parks and streets' green areas. This rational can be supported by the observed maximum year average concentrations $\left(10.61 \mu \mathrm{g} / \mathrm{m}^{3}\right)$ detected in the green background region outside the city. Ammonia detected in all sites were less than, the $350 \mu \mathrm{g} / \mathrm{m}^{3}$ as $1 \mathrm{~h}$ average, the standard recommended by the local environmental agency (Environmental Agency Abu 2004) and the WHO.

Statistical evaluation and effect of metrological factors on pollutant levels

Average relative standard deviations in the ranges of 3.64$12.24,4.30-13.57,1.09-5.92$, and $3.39-13.23 \mathrm{ppm}$ were obtained for the determinations of $\mathrm{NO}_{2}, \mathrm{SO}_{2}, \mathrm{O}_{3}$, and $\mathrm{NH}_{3}$, respectively. Year average standard deviations in the ranges of 2.99-12.88, 3.32-5.02, 3.60-4.50, and 4.65-8.94 were, respectively, obtained for determined $\mathrm{NO}_{2}, \mathrm{SO}_{2}, \mathrm{O}_{3}$, and $\mathrm{NH}_{3}$. Standard deviation values obtained for $\mathrm{NO}_{2}$ and $\mathrm{NH}_{3}$ were shown relatively higher than $\mathrm{SD}$ values obtained for $\mathrm{SO}_{2}$ and $\mathrm{O}_{3}$ (Tables 1, 2).

Since meteorological parameters play an important role in the dispersion of emitted pollutants in atmosphere, the effects of humidity, wind speed, and temperature on the concentrations of studied gases were evaluated using the multiple regression analysis implemented in the SYSTATE software package. Table 3 shows the effects of the three parameters on the average concentrations of determined gases at different sites and on the overall averages.

The paired $t$ test was applied to evaluate the correlations between changes in concentrations of measured gases and changes occurred in the three meteorological parameters during the time interval of this investigation; $t \leq 1.483$, $0.390,1.950$, and 0.998 were obtained for the effects of humidity on $\mathrm{NO}_{2}, \mathrm{SO}_{2}, \mathrm{O}_{3}$, and $\mathrm{NH}_{3}$ concentrations, respectively. Changes in wind speed revealed $t \leq 1.452$, $1.175,1.829$, and 1.385 on $\mathrm{NO}_{2}, \mathrm{SO}_{2}, \mathrm{O}_{3}$, and $\mathrm{NH}_{3}$ concentrations, respectively. These $t$ values are less than the critical values indicating insignificant effects for humidity and wind speed on the concentrations of measured gases at $95 \%$ confidence level; $t \leq 1.609,1.414,4.165$, and 3.379 were respectively obtained for the effect of temperature on $\mathrm{NO}_{2}, \mathrm{NH}_{3}, \mathrm{SO}_{2}$, and $\mathrm{O}_{3}$. These values indicate that temperature had insignificant effects on $\mathrm{NO}_{2}$ and $\mathrm{NH}_{3}$ and significant effects on $\mathrm{SO}_{2}$ and $\mathrm{O}_{3}$ concentrations at $95 \%$ confidence level.

Probability $p$ values in the range of $0.10-0.896$ were obtained for the effects of humidity and wind speed on

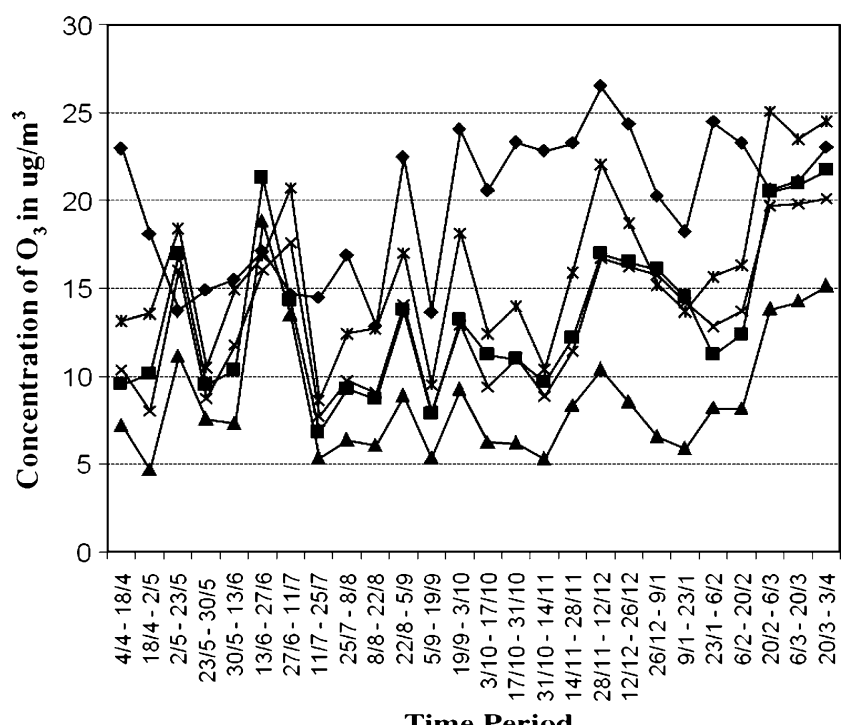

Time Period

Fig. 4 Concentration of $\mathrm{O}_{3}$ in $\left(\mu \mathrm{g} / \mathrm{m}^{3}\right)$ at different sites versus time in the period 4th April 2005 to 3rd April 2006. Measurements were done in 26 batches each of which lasted 14 days exposure interval. (filled diamonds) background area, (filled squares) industrial area, (filled triangles) traffic area, (ex marks) commercial area and (asterisks) residential area 


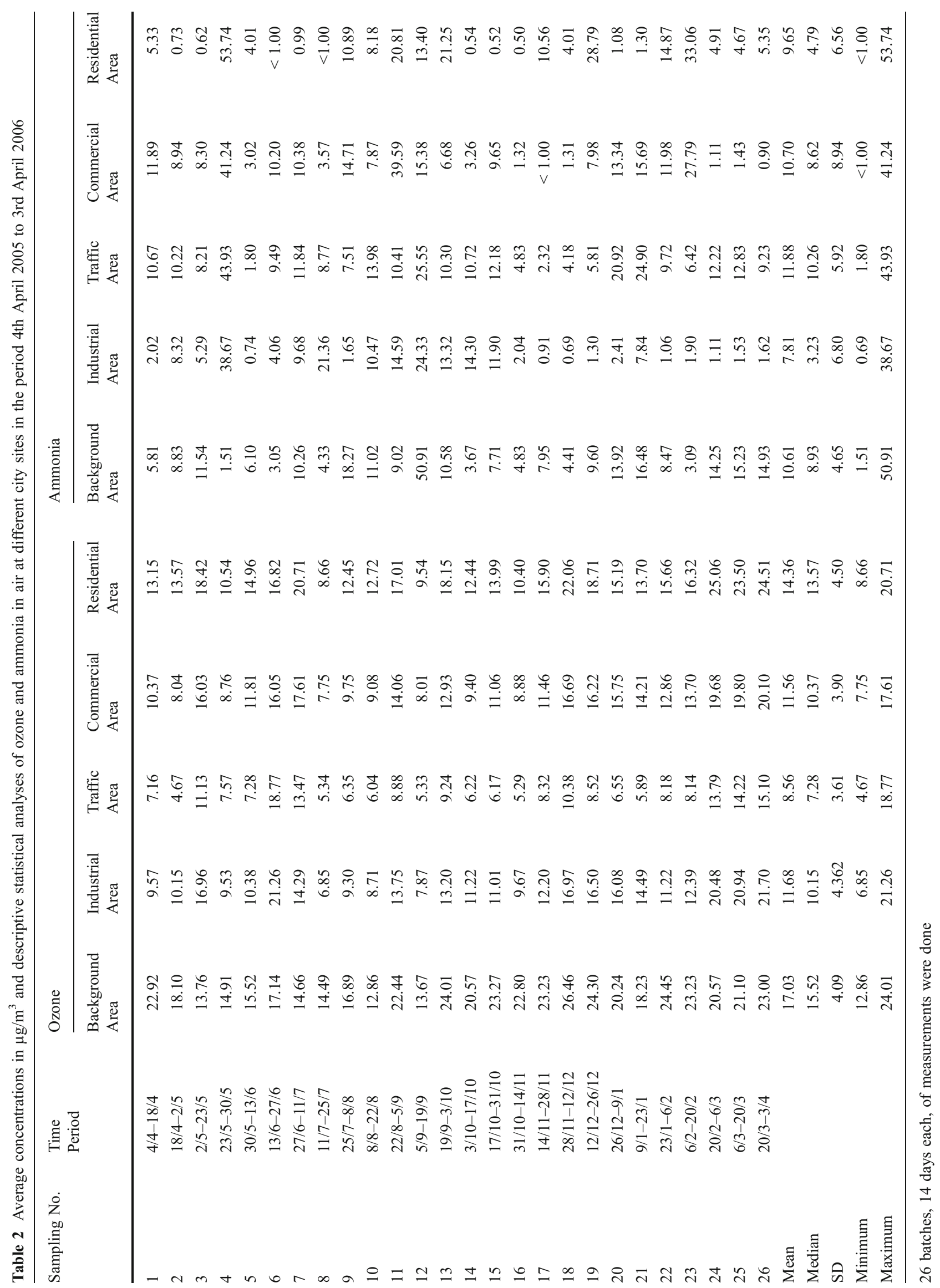




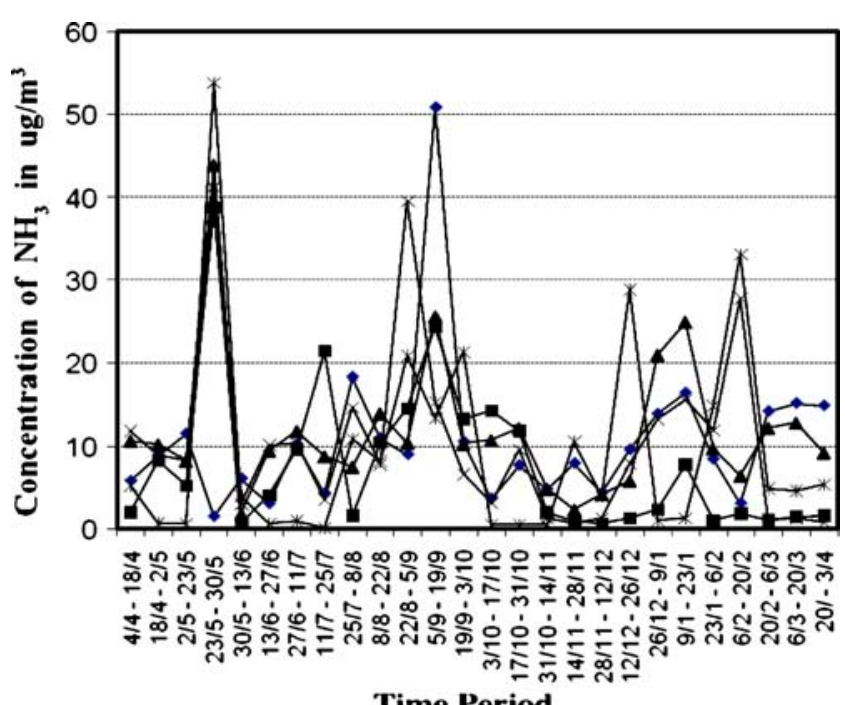

Time Period

Fig. 5 Concentrations of $\mathrm{NH}_{3}$ in $\left(\mu \mathrm{g} / \mathrm{m}^{3}\right)$ at different sites versus time in the period 4th April 2005 to 3rd April 2006. Measurements were done in 26 batches each of which lasted 14 days exposure interval. (filled diamonds) background area, (filled squares) industrial area, (filled triangles) traffic area, (ex marks) commercial area and (asterisks) residential area measured gas concentrations. These values indicated insignificant correlations between the two parameters and $\mathrm{NO}_{2}, \mathrm{SO}_{2}, \mathrm{O}_{3}$, and $\mathrm{NH}_{3}$ concentrations at $95 \%$ confidence level. Temperature had shown insignificant correlations with $\mathrm{SO}_{2}$ and $\mathrm{O}_{3}$ concentrations as shown by the low probability $p$ values obtained $(p=0.002-0.016)$. The effects of temperature on $\mathrm{NO}_{2}$ and $\mathrm{NH}_{3}$ gave significant correlations as indicated by the $p$ values of $0.122-7.47$ obtained at 95\% confidence level.

Average correlation coefficients between the four pollutants' concentrations and the three meteorological parameters are given in Table 3. Values between 0.200 and 0.722 were obtained indicating nonlinear correlations.

\section{Conclusion}

Concentrations of nitrogen dioxide, sulfur dioxide, ozone, and ammonia were determined over a year using the passive sampling associated with ion chromatographic and potentiometric detections. IVL samplers were used for collecting $\mathrm{NO}_{2}$ and $\mathrm{SO}_{2}$ whereas Ogawa samplers were

Table 3 Effects of temperature, humidity, and wind speed meteorological parameters on the average concentrations of gas pollutants at different sites and on the overall averages of all sites

\begin{tabular}{|c|c|c|c|c|c|c|c|}
\hline \multirow[t]{2}{*}{ Site } & \multicolumn{2}{|c|}{ Temperature } & \multicolumn{2}{|c|}{ Humidity } & \multicolumn{2}{|c|}{ Wind Speed } & \multirow[t]{2}{*}{$R$} \\
\hline & $t$ test & $P$ value & $t$ test & $P$ value & $t$ test & $P$ value & \\
\hline \multicolumn{8}{|l|}{ Nitrogen dioxide } \\
\hline Industrial & 1.123 & 0.283 & 1.483 & 0.152 & 1.452 & 0.168 & 0.518 \\
\hline Traffic & 0.469 & 0.644 & 0.679 & 0.504 & 0.536 & 0.597 & 0.249 \\
\hline Commercial & 1.609 & 0.122 & 1.326 & 0.198 & 1.319 & 0.201 & 0.459 \\
\hline Residential & 0.853 & 0.403 & 0.448 & 0.658 & 0.723 & 0.478 & 0.475 \\
\hline Overall Average & 0.709 & 0.486 & 1.135 & 0.296 & 1.114 & 0.277 & 0.438 \\
\hline \multicolumn{8}{|l|}{ Sulfur dioxide } \\
\hline Industrial & 3.470 & 0.002 & 0.328 & 0.746 & 1.175 & 0.253 & 0.692 \\
\hline Traffic & 2.943 & 0.008 & 0.225 & 0.824 & 0.261 & 0.797 & 0.659 \\
\hline Commercial & 4.165 & 0.000 & 0.390 & 0.700 & 0.806 & 0.429 & 0.765 \\
\hline Residential & 3.084 & 0.005 & 0.048 & 0.962 & 1.082 & 0.291 & 0.680 \\
\hline Overall Average & 3.615 & 0.002 & 0.222 & 0.826 & 0.882 & 0.387 & 0.722 \\
\hline \multicolumn{8}{|l|}{ Ozone } \\
\hline Industrial & 2.724 & 0.012 & 0.715 & 0.482 & 1.065 & 0.298 & 0.556 \\
\hline Traffic & 3.379 & 0.003 & 1.950 & 0.064 & 1.829 & 0.100 & 0.634 \\
\hline Commercial & 2.605 & 0.016 & 0.678 & 0.505 & 0.558 & 0.582 & 0.544 \\
\hline Residential & 2.737 & 0.012 & 0.939 & 0.358 & 0.869 & 0.394 & 0.541 \\
\hline Overall Average & 3.004 & 0.007 & 1.087 & 0.289 & 1.107 & 0.280 & 0.575 \\
\hline \multicolumn{8}{|l|}{ Ammonia } \\
\hline Industrial & 1.414 & 0.171 & 0.133 & 0.896 & 0.701 & 0.491 & 0.471 \\
\hline Traffic & 0.326 & 0.747 & 0.637 & 0.531 & 0.283 & 0.780 & 0.138 \\
\hline Commercial & 0.415 & 0.682 & 0.998 & 0.329 & 1.385 & 0.180 & 0.299 \\
\hline Residential & 0.608 & 0.549 & 0.272 & 0.788 & 0.463 & 0.648 & 0.159 \\
\hline Overall average & 0.322 & 0.750 & 0.398 & 0.694 & 0.839 & 0.411 & 0.200 \\
\hline
\end{tabular}

$R$ correlation coefficient 
used for collecting $\mathrm{O}_{3}$ and $\mathrm{NH}_{3}$. Five sites represent the industrial, traffic, commercial, residential, and background regions of the city were monitored in the course of this investigation. Concentrations lower than standards recommended for ambient air by the Local Environmental Agency and the World Health Organization were obtained. Detected concentrations were also found comparable to reported concentrations in some adjacent (Bouhamra and Abdul-Wahab 1999) and worldwide cities (Carmichael et al. 2003). Passive samplers were shown to be not only precise $(\mathrm{RSD} \leq 13.57)$ but also of low cost, low technical demand, and expediency in monitoring different locations.

Statistical evaluations of results obtained with meteorological parameters recorded during the same period of time were performed; $t$ test revealed insignificant effects for humidity and wind speed on $\mathrm{NO}_{2}, \mathrm{SO}_{2}, \mathrm{O}_{3}$, and $\mathrm{NH}_{3}$ concentrations at $95 \%$ confidence level. Insignificant effects for temperature on $\mathrm{NO}_{2}$ and $\mathrm{NH}_{3}$ concentrations while as significant effects on $\mathrm{SO}_{2}$ and $\mathrm{O}_{3}$ concentrations were observed. The probability $p$ values gave insignificant correlations between each of humidity and wind speed and concentrations of the four measured gases at $95 \%$ confidence level. Temperature showed significant correlations with $\mathrm{SO}_{2}$ and $\mathrm{O}_{3}$ and insignificant correlations with $\mathrm{NO}_{2}$ and $\mathrm{NH}_{3}$ concentrations. Nonlinear correlations $\left(R^{2} \leq 0.722\right)$ between the concentrations of the four measured gases and changes in the three meteorological parameters were obtained.

The low concentration of measured gases excluded them from being the possible cause for the high incidence rate of acute respiratory attacks reported in the city during the year $2004(90.1 \%$ of patients treated at the city public health clinics). Therefore, the finger was pointed out towards particulate matters (PM) originated from sand dunes surrounding the city and those produced as a consequence of the second Gulf War occurred in 2003. Gas pollutants and PM measured in some gulf cities, by the US Army Environmental Hygiene Agency, 9 months after the first Gulf War in 1991, showed normal concentrations for the former and two to five times greater concentrations than the US standard $\left(150 \mu \mathrm{g} / \mathrm{m}^{3}\right)$ for the latter. PM consists of $75 \%$ calcium and silica (originated from sand) and 10-23\% soot (originated from oil well fires and industrial sources) were obtained. This condition was most likely repeated in the region after the second Gulf War occurred in 2003. Particulate matters are known to penetrate the upper part of the airways and lung and can go deeply reaching the alveolar region. Sand and dust PM irritate skin and sensitive membranes of the eyes, nose, and throat and aggravate sinus and asthmatic conditions. Exposure to silica particulates can lead to cough, runny nose, shortness of breath, and the development of a benign, nonprogressive pneumoconiosis referred to as "Desert Lung Syndrome" (Winkenwerder 2002). Pollens and bacterial infections could possibly be of minor contributions but unfortunately there are no reported statistical records about that.

Open Access This article is distributed under the terms of the Creative Commons Attribution Noncommercial License which permits any noncommercial use, distribution, and reproduction in any medium, provided the original author(s) and source are credited.

\section{References}

Blum O, Bytnerowicz A, Manning WJ, Popovicheva L (1997) Ambient trropospheric ozone in the Carpathian Mountains and Kiev region. Environ Pollut 98:299-304. doi:10.1016/S02697491(97)00158-9

Bouhamra WS, Abdul-Wahab SA (1999) Description of outdoor air quality in a typical residential area in Kuwait. Environ Pollut 105:221-229. doi:10.1016/S0269-7491(98)00221-8

Brace S, Peterson DL (1998) Spatial patterens of tropospheric ozone in the Mount Rainier of the Cascade Mountains. Atmos Environ 32:3629-3637. doi:10.1016/S1352-2310(98)00077-6

Bytnerowicz A, Krupa SV, Cox R (2001) Proceedings of the International Symposium on Passive Sampling of Gaseous Air Pollutants in Ecological Research: Preface. Sci World 1:461462

Bytnerowicz A, Godzik B, Frączek W, Grodzinska K, Krywult M, Badea O, Barancok P, Blum O, Cerny M, Godzik S, Mankovska B, Manning W, Moravcik P, Musselman R, Oszlanyi J, Postelnicu D, Szdzuj J, Varsavova M, Zota M (2002) Distribution of ozone and other air pollutants in forests of the Carpathian Mountains in central Europe. Environ Pollut 116:3-25. doi:10.1016/S0269-7491(01)00187-7

Bytnerowicz A, Arbaugh MJ, Padgett PE, Davila A, Alexander D (2004) Ogawa ozone passive sampler range of measurements. Pacific Southwest Research Station, Albany Joint Fire Science Program, Final report $1-4$

Carballo R, Dall'Orto V, Balbo A, Rezzano I (2003) Determination of sulfide by flow injection analysis using a poly [Ni-(protoporphyrin IX)] chemically modified electrode. Sens Actuators B 88:155-161. doi:10.1016/S0925-4005(02)00319-2

Carmichael GR, Ferm M, Thongboonchoo N, Woo JH, Chan LY, Murano K, Viet PH, Mossberg C, Bala R, Boonjawat J, Upatum P, Mohan M, Adhikary SP, Shrestha AB, Pienaar JJ, Brunke EB, Chen T, Jie T, Guoan D, Peng LC, Dhiharto S, Harjanto H, Jose AM, Kimani W, Kirouane A, Lacaux JP, Richard S, Barturen O, Cerda JC, Athayde A, Tavares T, Cotrina JS, Bilici E (2003) Measurements of sulfur dioxide, ozone and ammonia concentrations in Asia, Africa and South America using passive samplers. Atmos Environ 37:1293-1308. doi:10.1016/S13522310(02)01009-9

Christie S, Scorsone E, Persaud K, Kvasnik F (2003) Remote detection of gaseous ammonia using the near infrared transmission properties of polyaniline. Sens Actuators B 90(1-3):163169. doi: 10.1016/S0925-4005(03)00036-4

Cox RM (2003) The use of passive sampling to monitor forest exposure to $\mathrm{O}_{3}, \mathrm{NO}_{2}$ and $\mathrm{SO}_{2}$ : a review and some case studies. Environ Pollut 126:301-311. doi:10.1016/S0269-7491(03)00243-4

Cox RM, Malcolm JW (1999) Passive ozone monitoring for forest health assessment. Water Air Soil Pollut 116:339-434. doi:10.1023/A:1005285026276

Cruz LPS, Campos VP, Silva AMC, Tavares TM (2004) A field evaluation of a $\mathrm{SO}_{2}$ passive sampler in tropical industrial and 
urban air. Atmos Environ 38:6425-6429. doi:10.1016/j.atmos env.2004.07.022

De Leeuw F, Sluyter R, De Paus T (1999) Air pollution by ozone in Europe in 1997 and summer 1998. European Environment Agency, Copenhagen Topic report No 3

Demmers TGM, Burgess LR, Short JL, Philips VR, Clark JA, Wathes CM (1998) First experiences with methods to measure ammonia emissions from naturally ventilated cattle buildings in the UK. Atmos Environ 32:285-293. doi:10.1016/S1352-2310(97)00197-0

Do JS, Shieh RY (1996) Electrochemical nitrogen dioxide gas sensor based on solid polymeric electrolyte. Sens Actuators B 37:19-26. doi:10.1016/S0925-4005(97)80068-8

Egan ML, Dubois L (1974) The determination of ammonium ion in airborne particulates with selective electrodes. Anal Chim Acta 70:157-167. doi:10.1016/S0003-2670(01)82922-6

Eipel C, Jeroschewski P, Steinke I (2003) Determination of ozone in ambient air with a chemiluminescence reagent film detector. Anal Chim Acta 491:145-153. doi:10.1016/S0003-2670(03)00797-9

Environmental Agency Abu Dhabi (2004) Standards and limits for pollution to air and marine environments occupational exposure pesticides and chemical use. Technical guidance document TG0003R. Environmental Agency, Abu Dhabi

Fehsenfeld F (1995) Measurement of chemically reactive trace gases at ambient concentrations. In: Matson PA, Harris RC (eds) Biogenic trace gases: measuring emissions from soil and water. Blackwell Science, Oxford, p 206

Ferm M, Svanberg PA (1998) Cost efficient techniques for urban and background measurements of $\mathrm{SO}_{2}$ and $\mathrm{NO}_{2}$. Atmos Environ 32:1377-1381. doi:10.1016/S1352-2310(97)00170-2

Frączek W, Bytnerowicz A, Arbaugh MJ (2003) Use of geostatistics to estimate surface ozone patterns. In: Bytnerowicz A, Arbaugh MJ, Alonso R (eds) Ozone air pollution in the sierra Nevada: distribution and effects on forests. Developments in environmental science. Elsevier, Amsterdam, pp 215-247

Gilbert NL, Woodhouse S, Stieb DM, Brook JR (2003) Ambient nitrogen dioxide and distance from a major highway. Sci Total Environ 312:43-46. doi:10.1016/S0048-9697(03)00228-6

Gorecki T, Namiesnik J (2002) Passive sampling. Trends Analyt Chem 21(4):276-291. doi:10.1016/S0165-9936(02)00407-7

Guo Z, Zhang X, Gao Y, Li Y, Chang W, Ci Y (2003) Continuous monitoring of sulfur dioxide with a gas permeation denuderbased system. Mikrochim Acta 141:183-189. doi:10.1007/ s00604-002-0943-3

Harvard School of Public Health, Department of Environmental Health (2001) Protocol for ozone measurement using the ozone passive sampler badge. URL: http://www.ogawausa.com/protocol.html

Hjuler K, Dam-Johansen K (1993) Design of a flue gas probe for ammonia measurement. Anal Chim Acta 282(3):703-709. doi:10.1016/0003-2670(93)80135-8

Huang H, Dasgupta PK (1997) Electrochemical sensing of gases based on liquid collection interfaces. Electroanalysis 9:585-591. doi:10.1002/elan.1140090802

Ibrahim I, Cemal Y, Humeyra B (1996) Construction and response characteristics of a sulfite/hydrogensulfite-selective all-solid-state contact electrode based on the 4-methylpiperidinedithiocarbamate complex of mercury(II). Analyst (Lond) 121:1873-1876. doi:10.1039/an9962101873

Kifune I, Oikawa K (1979) Determination of trace amounts of ammonia and lower amines in the atmosphere by ion chromatography. Jpn Analyst 28(10):587-590

Koutrakis P, Wolfson JM, Bunyaviroch A, Froelich SE, Hirano K, Mulik JD (1993) Measurement of ambient ozone using a nitritesaturated filter. Anal Chem 65:210-214. doi:10.1021/ac00051a004

Lan TTN, Nishimura R, Tsujino Y, Imamura K, Warashina M, Hoang NT, Maeda Y (2004) Atmospheric concentrations of sulfur dioxide, nitrogen oxides, ammonia, hydrogen chloride, nitric acid, formic and acetic acids in the south of Vietnam measured by the passive sampling method. Anal Sci 20:213-217. doi:10.2116/analsci.20.213

Lee K, Parkhurst WJ, Jianping X, Ozkaynak AH, Neuberg D, Spengler JD (2004) Outdoor/indoor/personal ozone exposures of children in Nashville, Tennessee. J Air Waste Manag Assoc 54(3):352-359

Leuning R, Freney JR, Denmead OT, Simpson JR (1967) A sampler for measuring atmospheric ammonia flux. Atmos Environ 19 (7):1117-1124. doi:10.1016/0004-6981(85)90196-9

Matsumoto J, Hirokawa J, Akimoto H, Kajii Y (2001) Direct measurement of $\mathrm{NO}_{2}$ in the marine atmosphere by laser induced fluorescence technique. Atmos Environ 35:2803-2814. doi:10.1016/S1352-2310(01)00078-4

Mikuska P, Vecera Z (2000) Effect of complexones and tensides on selectivity of nitrogen dioxide determination in air with a chemiluminescence aerosol detector. Anal Chim Acta 410:159165. doi:10.1016/S0003-2670(00)00710-8

Mukerjee S, Smith LA, Norris GA, Morandi MT, Gonzaless M, Noble CA, Neas LM, Ozkaynak AH (2004) Field method comparison between passive air samplers and continuous monitors for VOCs and $\mathrm{NO}_{2}$ in El-Paso, Texas. J Air Waste Manage Assoc 54:307-319

Namiesnik J, Zabiegala B, Kot-Wasik A, Partyka M, Wasik A (2005) Passive sampling and/or extraction techniques in environmental analysis: a review. Anal Bioanal Chem 381:279-301. doi:10.1007/s00216-004-2830-8

Palmes ED, Gunnison AF (1973) Personal monitoring device for gaseous contaminants. J Am Ind Hyg Assoc 34:78-81

Pandurangappa M, Balasubranian N (1996) Extractive spectrophotometric determination of trace amounts of nitrogen dioxide, nitrite, and nitrate. Mikrochim Acta 124:137-146. doi:10.1007/BF01244966

Przybylko ARM, Thomas CLP, Anstice PJ, Fielden PR, Brokenshire J, Irons F (1995) The determination of aqueous ammonia by ion mobility spectrometry. Anal Chim Acta 311(1):77-83. doi:10.1016/0003-2670(95)00177-2

Ray JD (2001) Spatial Distribution of tropospheric ozone in national parks of California: interpretation of passive sampler data. Sci World 1:483-497

Robinson JK, Bollinger MJ, Birks JW (1999) Luminol $/ \mathrm{H}_{2} \mathrm{O}_{2}$ chemiluminescence detector for the analysis of nitric oxide in exhaled breath. Anal Chem 71:5131-5136. doi:10.1021/ac990646d

Royset O, Sivertsen B (1998) Air quality monitoring component, Mission 10th report, Environmental Information and Monitoring Program, DANIA, Egypt

Segundo MA, Rangel AOSS (2001) A gas diffusion sequential injection system for the determination of sulfur dioxide in wines. Anal Chim Acta 427:279-286. doi:10.1016/S0003-2670(00)01197-1

Sellien W, Czolk R, Reichert J, Ache HJ (1992) Development of an optical-chemical sensor for the detection of ammonium ions. Anal Chim Acta 269(1):83-88. doi:10.1016/0003-2670(92)85136-T

Shiavon G, Zotti G, Bontempelli G, Farnia G, Sandona G (1990) Amperometric monitoring of ozone in gaseous media by gold electrodes supported on ion exchange membranes (solid polymer electrolytes). Anal Chem 62:293-298. doi:10.1021/ac00202a013

Shimizu Y, Nishi H, Suzuki H, Maeda K (2000) Solid state $\mathrm{NO}_{\mathrm{x}}$ sensor combined with NASICON and $\mathrm{Pb}-\mathrm{Ru}$-based pyrochloretype oxide electrode. Sens Actuat B 65(1-3):141-143. doi:10.1016/S0925-4005(99)00442-6

Sritharathikhun P, Oshima M, Wei Y, Simon J, Motomizu S (2004) Online collection/concentration and detection of sulfur dioxide in air by flow-injection spectrophotometry coupled with a chromatomembrane cell. Anal Sci 20(1):113-118. doi:10.2116/analsci.20.113

Stern AC (1968) Analysis monitoring and surveying, vol. II. Academic Press, New York

Strehlitz B, Gründig B, Kopinke H (2000) Sensor for amperometric determination of ammonia and ammonia-forming enzyme reactions. Anal Chim Acta 403(1-2):11-23. doi:10.1016/S0003-2670 (99)00594-2 
Thompson M, Krull UJ, Bendell-Young LI (1983) The bilayer lipid membrane as a basis for a selective sensor for ammonia. Talanta 30(12):919-924. doi:10.1016/0039-9140(83)80214-8

Thornton JA, Wooldridge PJ, Cohen RC (2000) Atmospheric $\mathrm{NO}_{2}$ : in situ laser-induced fluorescence detection at parts per trillion mixing ratios. Anal Chem 72:528-539. doi:10.1021/ac9908905

Winkenwerder W (2002) Environmental exposure report, particulate matters, Gulf War Illnesses, Medical Readiness and Military Deployments, US department of Defense, 2001211-0000007 Ver 2, URL: http://www.gulflink.osd.mil/library/env_exp.jsp

Winquist F, Spetz A, Lundstrom I, Danielsson B (1984) Determination of ammonia in air and aqueous samples with a gas-sensitive semiconductor capacitor. Anal Chim Acta 164:127-136. doi:10.1016/S0003-2670(00)85624-X

World Health Organization (2000) Air quality guidelines for Europe, 2nd edn. WHO, Copenhagen

Wu F, He Z, Meng H, Yuan L, Zeng Y (1998) Determination of sulfite in sugar and sulfur dioxide in air by chemiluminescence using the Ru(bipy) 32+ - KBrO3 system. Analyst (Lond) 123:2109-2112. doi:10.1039/a803618g
Yagoub MM (2004) Monitoring of urban growth of a desert city through remote sensing: Al-Ain (UAE) between 1976 and 2000. Int J Remote Sens 25(6):1063-1076. doi:10.1080/0143116031000156792

Yanagisawa Y, Nishimura H (1982) A badge-type personal sampler for measurement of personal exposure to $\mathrm{NO}_{2}$ and $\mathrm{NO}$ in ambient air. Environ Int 8:235-242. doi:10.1016/0160-4120(82)90033-2

Yang XF, Guo XQ, Zhao YB (2002) Novel spectrofluorimetric method for the determination of sulfite with rhodamine $B$ hydrazide in a micellar medium. Anal Chim Acta 456:121-128. doi:10.1016/S0003-2670(02)00005-3

Yang Y, Zhang X, Korenaga T, Higuchi K (2007) Determination of passive-sampled sulfur dioxide in ambient air as sulfate ion by flow injection analysis with an in-line reaction column. Talanta 45:445-450. doi:10.1016/S0039-9140(97)00152-5

Yokohama City Research Institute for Environmental Science (2005) $\mathrm{NH}_{3}$ sampling protocol using the Ogawa sampler, URL: http:// www.ogawausa.com/pdfs/pronh3.pdf

Yokohama City Research Institute for Environmental Science (2006) NO, $\mathrm{NO}_{2}, \mathrm{NO}_{\mathrm{x}}$ and $\mathrm{SO}_{2}$ sampling protocol using the Ogawa sampler, URL: http://www.ogawausa.com/pdfs/prono-noxno2so206.pdf 